\title{
HAART restores the frequency of regulatory T cells (Tregs) among HIV/AIDS patients
}

\author{
M Suthandhira ${ }^{1}$, H Durgadevi', OR Krishnarajasekar², K Raja², B Rayvathy², Sowmya Swaminathan ${ }^{3}$, \\ Luke Elizabeth Hanna ${ }^{3}$, S Anbalagan ${ }^{3}$, Elanchezhiyan Manickan ${ }^{1 *}$ \\ From 2nd International Science Symposium on HIV and Infectious Diseases (HIV SCIENCE 2014) \\ Chennai, India. 30 January - 1 February 2014
}

\section{Background}

Immunosuppression is the hallmark HIV infection associated with gradual loss of CD4+Tcells. The effector immune response is regulated by CD4+CD25+Foxp3+ Tcells (Tregs). Enumeration of Tregs frequency showed equivocal results before and here we showed clearly their frequency by flowcytometry.

\section{Methods}

One hundred and eight individuals comprising of 71 HIV positive patients (44 patients undergoing HAART and 27 without HAART) and 37 HIV negative healthy controls. PBMCs were isolated and stained with CD4/ FITC, CD25/APC, FoxP3/PE antibodies (BD Pharmingen) and analyzed for Tregs frequency by flowcytometer (BD FACS Calibur).

\section{Results}

Our study showed that healthy controls had a Tregs frequency of $4.1 \%$. When Tregs frequency analyzed among HIV/AIDS patients who are yet to receive HAART we found a significant reduction in Tregs population i.e. $1.2 \%$. Encouragingly this deep plunge in Tregs population was found to be restored and surged upon HAART up to $12.6 \%$. However, these changes in percentages did not alter based on their gender or age or absolute CD4 count of the study population.

\section{Conclusion}

HAART is known to decrease viral load and improve the patient's CD4 cells count. Here we report that HAART has improved the Tregs frequency. It is yet to

\footnotetext{
* Correspondence: emanickan@yahoo.com

'Department of Microbiology, Dr. ALM PG IBMS, University of Madras,

Taramani, Chennai, India

Full list of author information is available at the end of the article
}

be known that the consequence of resurging Tregs during HIV/AIDS.

\section{Authors' details}

'Department of Microbiology, Dr. ALM PG IBMS, University of Madras, Taramani, Chennai, India. ${ }^{2}$ Govt. Hospital of Thoracic Medicine, Tambaram Sanatorium, Chennai, India. ${ }^{3}$ National Institute for Research in Tuberculosis (ICMR), Chetpet, Chennai, India.

Published: 27 May 2014

\section{doi:10.1186/1471-2334-14-S3-E1}

Cite this article as: Suthandhira et al:: HAART restores the frequency of regulatory T cells (Tregs) among HIV/AIDS patients. BMC Infectious Diseases 2014 14(Suppl 3):E1.
Submit your next manuscript to BioMed Central and take full advantage of:

- Convenient online submission

- Thorough peer review

- No space constraints or color figure charges

- Immediate publication on acceptance

- Inclusion in PubMed, CAS, Scopus and Google Scholar

- Research which is freely available for redistribution

Submit your manuscript at www.biomedcentral.com/submit
C Biomed Central 